\title{
MONITORING HAZARDOUS WASTE ELIMINATED FROM A MODERN ROTARY KILN
}

\section{Loredana Irena Negoițăă ${ }^{1}$ Maria Popa ${ }^{1 a}$}

${ }^{1}$ Petroleum-Gas University of Ploiești, Blvd. București no.39, irena.negoita@gmail.com, Romania

\begin{abstract}
Hazardous waste is that solid or liquid waste that contain constituents with one or more properties set out in Annex IE of Emergency Ordinance no. 78/2000 from 426/2001 law.

The installation for disposing hazardous waste which under review is an installation with modern burning, equipped with a waste deposit, rotary kiln, heat regenerator, system for gas purification, automated control of operating parameters and emission monitoring system.

The paper is an analysis of the functioning of the burning of hazardous waste.

The analysis of the way of functioning highlights the fact that in the burning installation there are used BAT techniques (Best Available Techniques) and also the level of emissions and the monitoring are under ALV level (admissible limit values) established by the legislation.
\end{abstract}

Keywords: BAT techniques, emissions, hazardous waste, incineration plant, monitoring

\section{Introduction}

The waste means the technological residues, products and materials with exceeded shelf life, the physical worn products that are no longer useful, as well as household waste. The common and fundamental element to the regional strategies and policies on the management of waste is represented by the approach known as Sustainable Waste Management (SWM) as shown in figure 1.[1], [2], [3]

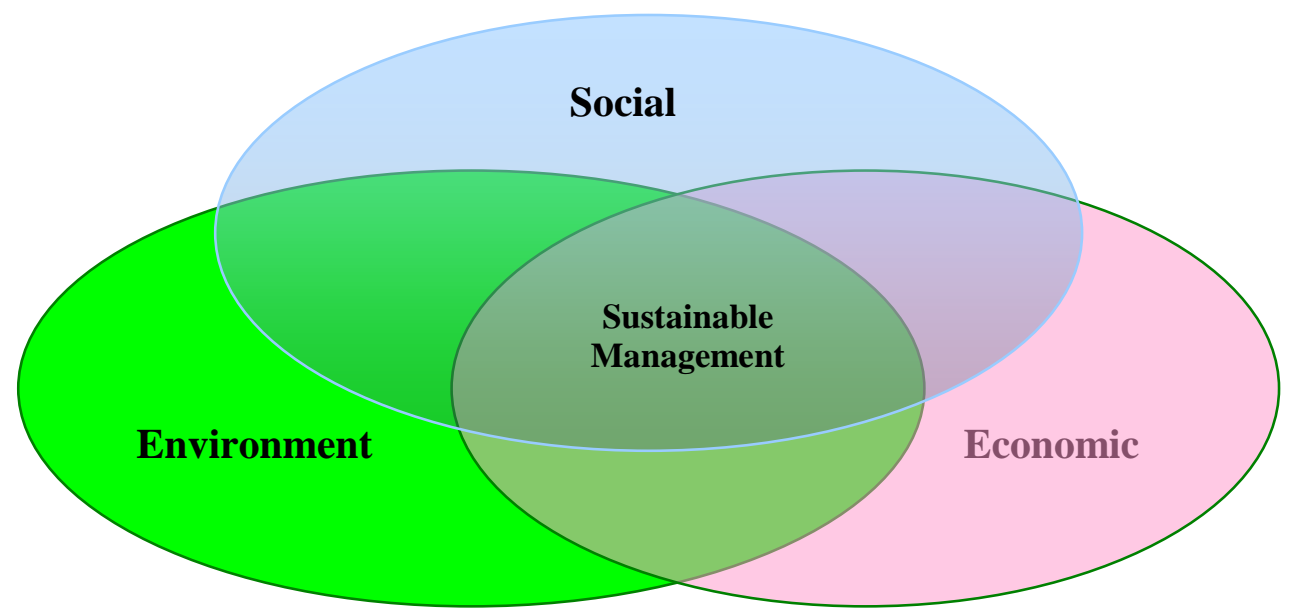

Fig.1: Sustainable Waste Management 
Sustainable Waste Management (SWM) as shown in Figure 2 is vital for the human community whereas: the capacity of deposits decreases continuously, while building new ones is a difficult and expensive process; many materials which are found in the waste volumes are rare natural resources that have to be recovered; the activity of collecting and sorting of materials which are found in waste volumes can be an opportunity to starting a business; a system that is not based on a single variant (ie: the existence of at least one alternative) is more flexible to economical, technological and legislative changes. [1], [2]

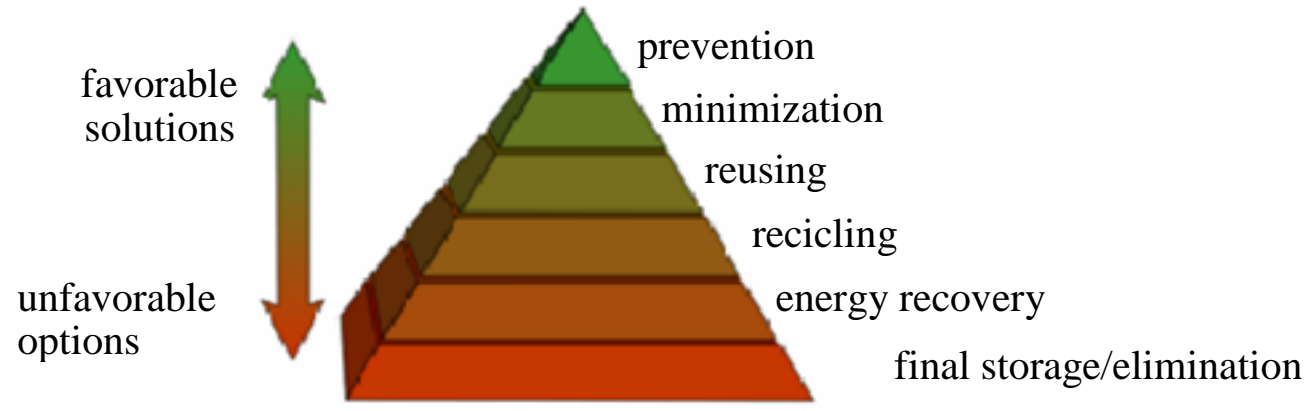

Fig. 2: The hierarchy in waste managemet solutions

Therefore, the economic aspects of SWM, also concern the conservation of natural resources, by harnessing the raw materials and consumables.

Waste management comprises the following steps

1. Waste collection;

2. Waste transportation;

3. Waste treatment.

The thermal processing of waste is a feasible option after recovery variants (collection, sorting, recycling) and before controlled storage.

The incineration means removing the waste by burning it at a temperature higher than $850^{\circ} \mathrm{C}$ in an incineration plant.

The incineration plant can be a fix or mobile technical installation and the equipment for the waste thermal treatment, with or without resulted heat recovery.

The incineration may be applied both on collected mixed municipal waste and only on the residual waste fraction. The composition of the municipal waste is preponderantly biodegradable and this hampers the incineration of the municipal waste without other fuels, leading to increased incineration costs per ton of municipal waste. That is why it is recommended the incineration of the residual waste from the municipal waste, the residual waste accounting the remaining waste after sorting the recyclable wastes. [2], [5]

In the case to the household waste, for example, from a tonne of incinerated waste there follows:

- 230-250 kg of ash - $25-40 \mathrm{~kg}$ waste gases - 20 - $22 \mathrm{~kg}$ of ferrous;

- $0.5-1.5 \mathrm{~kg}$ of nonferrous - $6000 \mathrm{Nm}^{3}$ of gases (8\% of resulted products from incineration)

The operating costs of an incineration plant range between $23-38 € /$ tonne and depend on the composition and the calorific power of the waste.

In addition to the residual and municipal waste, the incinerators can accept any type 
of waste. Depending on the accepted waste, the incinerators are special designed. For the hazardous waste, the incinerators must reach a much higher burning temperature than the incineration of non-hazardous wastes.

A waste incineration plant consists of the following areas of operation:

taking over the waste;

temporary storage, pre-treatment (if is necessary);

supplying in incineration unit;

the residual ash elimination and treatment;

the emissions treatment and recovery. [2], [3]

\section{Materials and Methods}

The main activity consists of incinerating the industrial and hazardous hospital waste in an installation-type System. Figure 3 is a diagram of the incineration plant with heat recovery for which it is analysed the monitoring stages. [2], [4], [5]

It is aimed to:

- $\quad$ minimize the potential risk and the pollution;

- $\quad$ reduce the quantity and the volume of waste;

- $\quad$ convert of the remaining substances in a form that allows the recovery or the storage thereof;

- $\quad$ convert and valorise the produced energy.

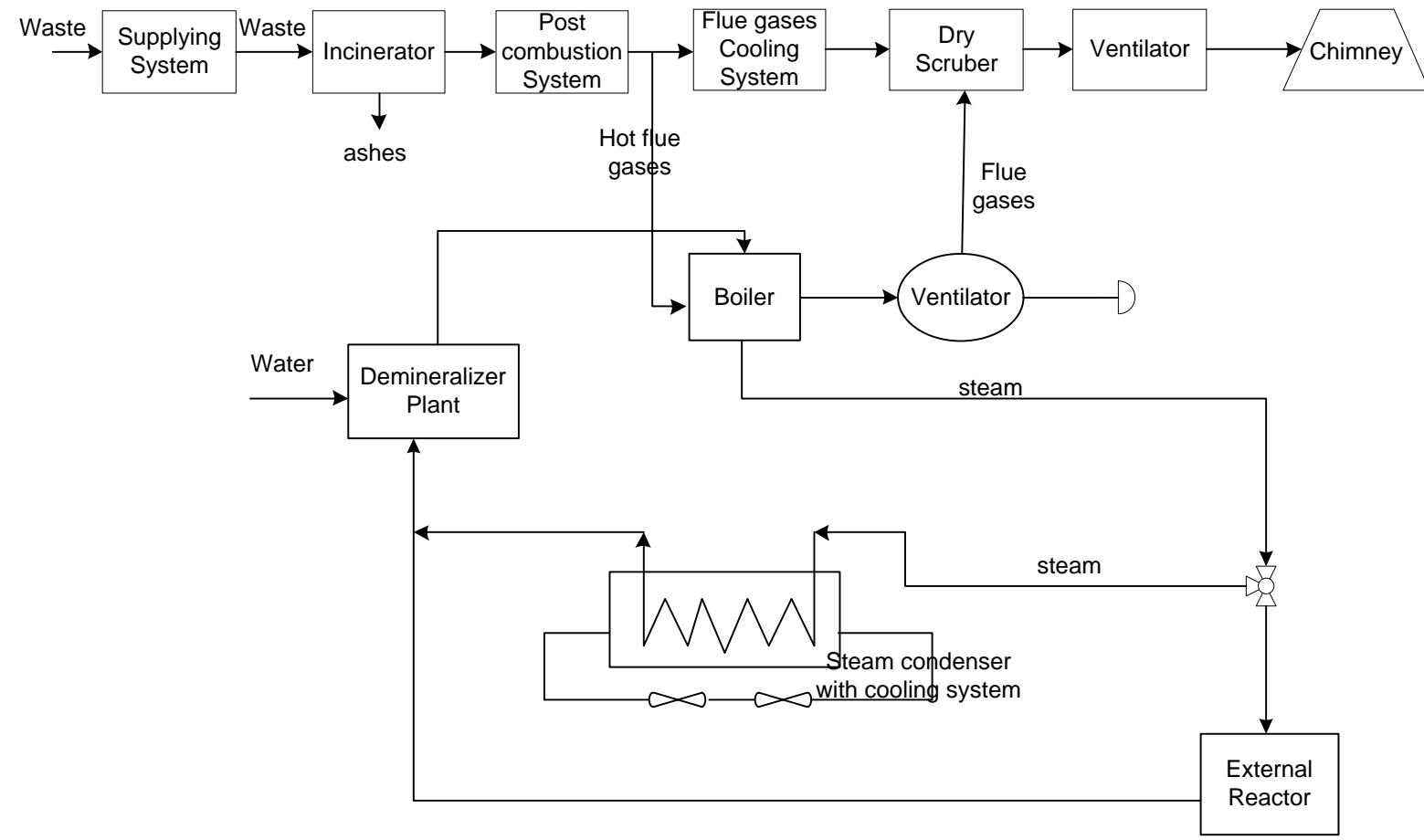

Fig.3: Diagram of waste incineration plant with heat recovery system

Detailed component of the steps in the incineration plant:

Receiving and preparing the solid waste for incineration; Placing waste in process equipment; Rotary kiln waste circulating in counter fuel; Boiler (heat exchanger) and turbine; Tower conditioning/gas treatment; Flue gas treatment plant; Ventilator- 
induced airflow; Cyclone; Wet scrubber; Separator mist droplets; Wastewater treatment plant; Chimney; Automations; Installation of continuous emission monitoring.

Description of the installation and the process flow:[5]

- Composition: rotary kiln (primary combustion chamber) as shown in Figure 4, an Afterburner (secondary combustion chamber) with 2 burners + one auxiliary burner (per room), conventionally-fuelled (LPG) connected to an air pollution control system, all controlled and monitored;

- Technological incineration flow: temporary storage and gobs preparation of waste for incineration; supplying the rotary kiln with waste; primary combustion; secondary combustion; cooling and heat recovery; treatment and discharge of gases into the atmosphere, systems shown in Figure 5 ( $a$ and b); disposal of ashes; automatic control of operating parameters; monitoring of emissions.

- $\quad$ total incineration capacity of 23,000 tonnes/year;
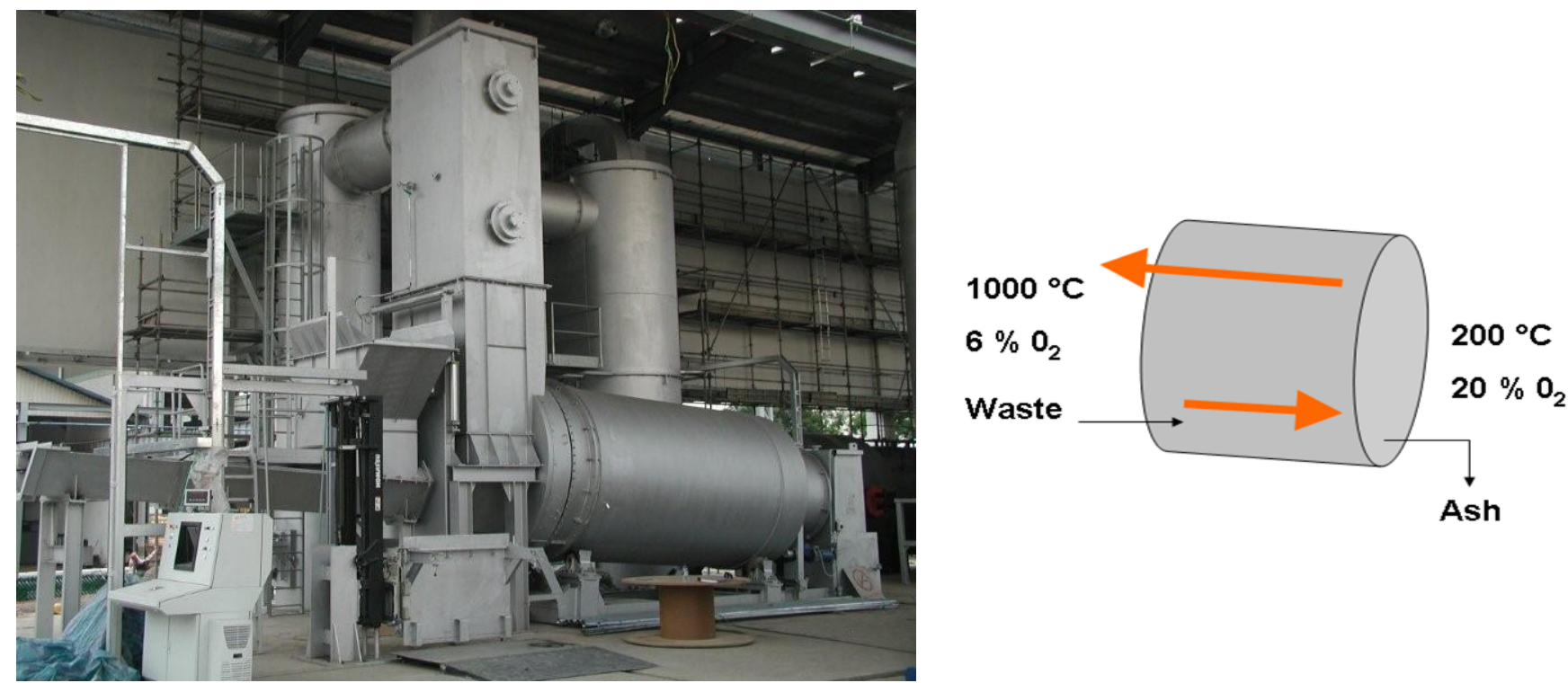

Fig. 4: Rotary kiln with waste circulating in counter fuel. The direction of gas and waste circulation into the rotary kiln

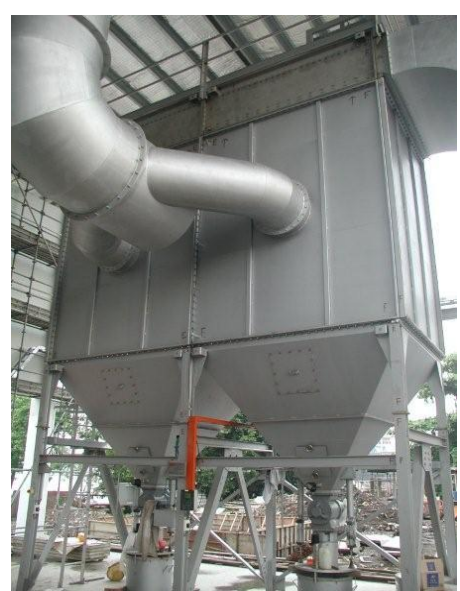

Fig. 5: a. Flue gases filter system.

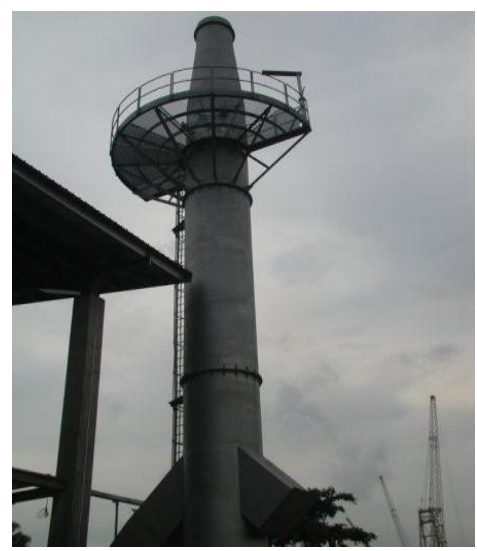

b. Exhaust chimney of flue gases 
Flue gas concentrations are monitored to ensure compliance with Annex 7 of GD 128/2002 on waste incineration. [8]

Installation for continuously monitoring the emission

The analyser continuously and independently monitors (records and prints) the following parameters:

- temperature: $-200^{\circ} \mathrm{C} \ldots+1370^{\circ} \mathrm{C}$;

- oxygen $\mathrm{O}_{2}: 0 \ldots 25 \%$;

- CO with $\mathrm{H}_{2}$ compensation: 0 ... 10000 ppm;

- NO: 0 ... 3000 ppm;

- $\mathrm{NO}_{2}: 0$... $500 \mathrm{ppm}$;

- How to measure $\mathrm{SO}_{2}$;

- How to measure HC (unburned hydrocarbons).

Total organic carbon (TOC) and dust are controlled by continuously monitoring the combustion temperature, excess oxygen and unburned hydrocarbons $(\mathrm{HC})$.

The incinerator ensures a burning level which provides a total carbon (TOC) of the slag and ash below $3 \%$ and loss on calcination is less than $5 \%$ of the dry material.

Data of guarantee the installation of flue gas treatment - maximum concentrations of pollutants at the outlet from treatment plant - according to the prospectus installation are:

- powders - a maximum of $10 \mathrm{mg} / \mathrm{Nm} 3$;

- Cadmium - $0.05 \mathrm{mg} / \mathrm{Nm} 3$;

- heavy metals - $0.5 \mathrm{mg} / \mathrm{m3}$;

- dioxins and furans $-0.1 \mathrm{ng} / \mathrm{m} 3$.

On-site sources of emissions in the atmosphere are:

- sources fixed / stationary: combustion of natural gas and different categories of hazardous waste;

- mobile sources: transportation equipment, internal combustion engines.

The possible pollutants to be emitted into the atmosphere, according MEWF (Ministry of Environment, Water and Forests) Order 1144/2002 on the establishment of the Register of pollutants emitted to activity incineration are $\mathrm{CO}, \mathrm{CO}_{2}, \mathrm{NOx}, \mathrm{SO}$, heavy metals (As, $\mathrm{Cd}, \mathrm{Cr}, \mathrm{Cu}, \mathrm{Hg}, \mathrm{Ni}, \mathrm{Pb}, \mathrm{Zn}$ ), HCB, dioxins and furans, PAHs, chlorides, fluorides, PM10.

\section{Results and Discussion}

In hazardous waste incineration plant with heat recovery there are used the best available BAT techniques:[6]

- incineration rotary kilns are equipped with jacketed steel, with refractory protection $250-500 \mathrm{~mm}$ thick;

- $\quad$ automatic control of the combustion temperature $\left(T=850-1100^{\circ} \mathrm{C}\right.$ for at least 2 seconds), so that in the flue gases are no longer reflected to cargoes with the undamaged substances;

- stable combustion process, which allows the incineration of various compositions;

- $\quad$ stages of combustion are separate from one another and individually adjusted; due to this fact, respecting the values of permitted emissions is not a problem when it comes to environmental protection;

- $\quad$ reduction by $95-98 \%$ of the volume and weight of the treated waste

- heat recovery and its use in domestic and industrial purposes, which makes the installation economically profitable; 
- $\quad$ efficient system for extracting the slag which removes and cools the solid residues resulting from the rotary kiln.

Depending on each type of waste, an incineration program is drawn up, taking into account the following criteria:

- calorific value;

- $\quad$ water content;

- $\quad$ content of halogen ( $\mathrm{F}, \mathrm{Cl}, \mathrm{Br}, \mathrm{I})$;

- content of sulphur and nitrogen;

- $\quad$ content of heavy metals;

- content of thermostable organic compounds (eg. Polycyclic aromatic hydrocarbons)

The quantities and composition of waste that may be incinerated daily:

- Solid waste - 52\%; approx. 35.9 t/day;

- pasty waste - 30\%; approx. 20.7 t/day;

- Liquid waste - 8\%; approx. 5.5 t/day;

- Packaging - 8\%; approx. 5.5 t/day.

The maximum content of pollutants are found in waste subject to incineration will not exceed following maximum values:

- $\quad$ powders - $200 \mathrm{mg} / \mathrm{m}^{3}$; Soot/unburned material - $20 \mathrm{mg} / \mathrm{m}^{3} ; \mathrm{SO} 2-250 \mathrm{mg} / \mathrm{m}^{3}$;

- $\quad \mathrm{HF}-7 \mathrm{mg} / \mathrm{m}^{3} ; \mathrm{HCl}-150 \mathrm{mg} / \mathrm{m}^{3} ; \mathrm{As}-0.3 \mathrm{mg} / \mathrm{m}^{3} ; \mathrm{Cd}-0.15 \mathrm{mg} / \mathrm{m}^{3}$; Co - 0.3 $\mathrm{mg} / \mathrm{m}^{3}$;

- $\quad \mathrm{Cr}-0.95 \mathrm{mg} / \mathrm{m}^{3} ; \mathrm{Pb}-0.19 \mathrm{mg} / \mathrm{m}^{3} ; \mathrm{Ni}-0.3 \mathrm{mg} / \mathrm{m}^{3}$;

- $\quad \mathrm{Hg}+\mathrm{Hg}$ compounds - of which $10 \%$ metal $-1 \mathrm{mg} / \mathrm{m}^{3} ; \mathrm{PCB}+\mathrm{PCP}-50 \mathrm{ppm}$;

- $\quad$ PCB content in a batch + CFP (subject to incineration) shall not exceed $5 \%$ of the incinerated.

In Table 1 there are presented the types of waste and the amount of net calorific value of the incinerated waste and in Table 2 there are presented the emission limit values for pollutants regarding waste incineration according to national legislation by GD 128/2002 amended by GD 268/2005.[7], [8], [9]

Table 1: Types of waste and normal calorific value to the incinerated waste [7],[8], [9]

\begin{tabular}{|l|l|l|l|}
\hline \multirow{2}{*}{ Waste type } & Comments and examples & \multicolumn{2}{|l|}{$\begin{array}{l}\text { NCV in original substance } \\
\text { (humidity included) }\end{array}$} \\
\cline { 3 - 4 } & & $\begin{array}{l}\text { Interval } \\
\text { GJ/t }\end{array}$ & $\begin{array}{l}\text { Media } \\
\text { GJ/t }\end{array}$ \\
\hline $\begin{array}{l}\text { Municipal solid waste } \\
\text { (MSW) }\end{array}$ & Mixed household waste & $6,30-10,50$ & 9 \\
\hline Voluminous waste & furniture, etc. & $10.5-16.8$ & 13 \\
\hline $\begin{array}{l}\text { Similar waste } \\
\text { MSW }\end{array}$ & $\begin{array}{l}\text { Similar with household waste, waste } \\
\text { generated from store, office }\end{array}$ & $7.6-12.6$ & 11 \\
\hline $\begin{array}{l}\text { Waste MSW after } \\
\text { recycling operations }\end{array}$ & $\begin{array}{l}\text { The fraction sifted from composting and } \\
\text { materials resulted by recovery } \\
\text { processes }\end{array}$ & $6.3-11.5$ & 10 \\
\hline Commercials waste & $\begin{array}{l}\text { The fraction collected separately from } \\
\text { offices, stores }\end{array}$ & $10-15$ & 12.5 \\
\hline Packaging waste & Packaging collected separately & $17-25$ & 20 \\
\hline
\end{tabular}




\begin{tabular}{|l|l|l|l|}
\hline $\begin{array}{l}\text { Refusals secondary } \\
\text { fuels (RDF) }\end{array}$ & $\begin{array}{l}\text { Flocculated material produce from } \\
\text { municipal and similar non-hazardous } \\
\text { waste }\end{array}$ & $11-26$ & 18 \\
\hline $\begin{array}{l}\text { Specify industrial } \\
\text { waste }\end{array}$ & Industrial plastic waste, paper & $18-23$ & 20 \\
\hline Hazardous waste & Chemical and special waste & $0.5-20$ & 9.75 \\
\hline \multirow{2}{*}{$\begin{array}{l}\text { Sludge from } \\
\text { wastewater }\end{array}$} & Crude (dehydrated to 25\% dry solid) & $1.7-2.5$ & 2.1 \\
\cline { 2 - 5 } & $\begin{array}{l}\text { Assimilated (dehydrated to 25\% dry } \\
\text { solid) }\end{array}$ & $0.5-1.2$ & 0.8 \\
\hline
\end{tabular}

Table 2: Emission Limit Values (ELV) for noxious according with national legislation by GD 128/2002 amended by GD 268/2005 regarding the incineration of waste [8], [9]

\begin{tabular}{|c|c|c|c|c|c|}
\hline \multirow[b]{2}{*}{ Parameter } & \multicolumn{2}{|c|}{$\begin{array}{c}\text { The daily average } \\
\mathrm{mg} / \mathrm{Nm}^{3}\end{array}$} & \multicolumn{2}{|c|}{$\begin{array}{c}\text { Average at } 30 \mathrm{~min} \\
\mathrm{mg} / \mathrm{Nm}^{3}\end{array}$} & \multirow{2}{*}{$\begin{array}{c}\begin{array}{c}\text { Annual average } \\
\mathbf{m g} / \mathrm{Nm}^{3}\end{array} \\
\text { BAT values }\end{array}$} \\
\hline & $\begin{array}{c}\text { Limit } \\
\text { according } \\
\text { D 2000/76/EU }\end{array}$ & BAT values & $\begin{array}{c}\text { Limit } \\
\text { according } \\
D \\
\text { 2000/76/EU }\end{array}$ & BAT values & \\
\hline $\begin{array}{l}\text { Total } \\
\text { powders }\end{array}$ & 10 & $0,1-10$ & 20 & $0,1-15$ & $0,1-2$ \\
\hline $\mathrm{HCl}$ & 10 & $0,1-10$ & 60 & $0,1-60$ & $0,3-5$ \\
\hline $\mathrm{HF}$ & 1 & $0,04-1$ & 4 & $0,1-2$ & $0,05-1$ \\
\hline $\mathrm{SO}_{2}$ & 50 & $0,1-50$ & 200 & $0,1-150$ & $0,1-30$ \\
\hline $\mathrm{NO}_{\mathrm{x}}$ & 200 & $40-200$ & 400 & $50-400$ & $70-180$ \\
\hline TOC & 10 & $0,1-10$ & 20 & $0,1-20$ & $0,01-5$ \\
\hline $\mathrm{CO}$ & 50 & $5-50$ & 100 & $5-100$ & $5-50$ \\
\hline $\mathrm{Hg}$ & 0,05 & $0,0003-0,03$ & $\mathrm{n} / \mathrm{a}$ & $0,0003-1$ & $0,0004-0,05$ \\
\hline$\overline{C d+T_{1}}$ & 0,05 & $0,0005-0,05$ & $n / a$ & & $0,0005-0,05$ \\
\hline $\begin{array}{l}\sum \text { other heavy } \\
\text { metals }\end{array}$ & 0,5 & $0,0013-0,5$ & $n / a$ & & $0,004-0,4$ \\
\hline $\begin{array}{l}\mathrm{PCCD} / \mathrm{PCDF} \\
\left(\mathrm{ngTEQ} / \mathrm{m}^{3}\right)\end{array}$ & 0,1 & $0,002-0,1$ & $n / a$ & & $0,0003-0,08$ \\
\hline
\end{tabular}

\section{Conclusions}

$\checkmark \quad$ Industrial waste incinerators operating under EU regulations are high-tech equipment, carefully designed, controlled and maintained to ensure environmental protection;

$\checkmark \quad$ It occurs the safe destruction of all harmful organic compounds from waste;

$\checkmark \quad$ It is performed the control of emissions to safe levels, generally well below those regulated;

$\checkmark \quad$ It occurs the proper treatment and safe disposal of any residues; 
$\checkmark \quad$ The industry of our society produces large quantities of hazardous waste and will continue to produce it in the future, even with considerable efforts in reducing the generation of waste. Moreover, the unregulated waste in present, which present a substantial risk if they are not properly managed, will become regulated in the next years. Even so, there are still contaminated areas and substantial amounts of "historic" hazardous waste to be properly managed.

\section{References}

1. Vassili J. Inglezakis, Konstantinos Maustakas, 2015, Household hazardous waste management: A review, Journal of Environmental Management, 150, pg. 310-321.

2. Clive Brereton, 1996, Municipal solid waste - incineration, air pollution control and ash management, Resources, Conservation and Recycling, 16, pg. 227-264.

3. William Piper, Tim Harvey, Hemu Mehta, 2005, Chapter 16 - Waste Management, Drilling Fluids Processing Handbook, pg. 367-412.

4. Boateng A. A., 2016, Chapter 12. Rotary Kiln Environmental Applications, Rotary Kilns (Second Edition), pg. 231-264.

5. Woodard \& Curran, Inc., 2006, Chapter 9. Solid Waste Treatment and Disposal, Industrial Waste Treatment Handbook (Second Edition), pg. 363-408.

6. European Commission, 2006, Integrated Pollution Prevention and Control, Reference Document on the Best Available Techniques for Waste Incineration, http://eippcb.jrc.ec.europa.eu/reference/BREF/wi bref 0806.pdf

7. Directiva 2000/76/CE a Parlamentului European și a Consiliului privind incinerarea deșeurilor,

content/uploads/2012/05/Directiva 200076 CE.pdf

8. HG 128/2002, privind incinerarea deșeurilor, http://www.mmediu.ro/beta/wpcontent/uploads/2012/05/2012-05-18 hg 128 2002.pdf

HG 268/2005, privind modificarea HG 128/2002 privind incinerarea deșeurilor, http://www.gnm.ro/otherdocs/nq3g5ivo1.pdf 